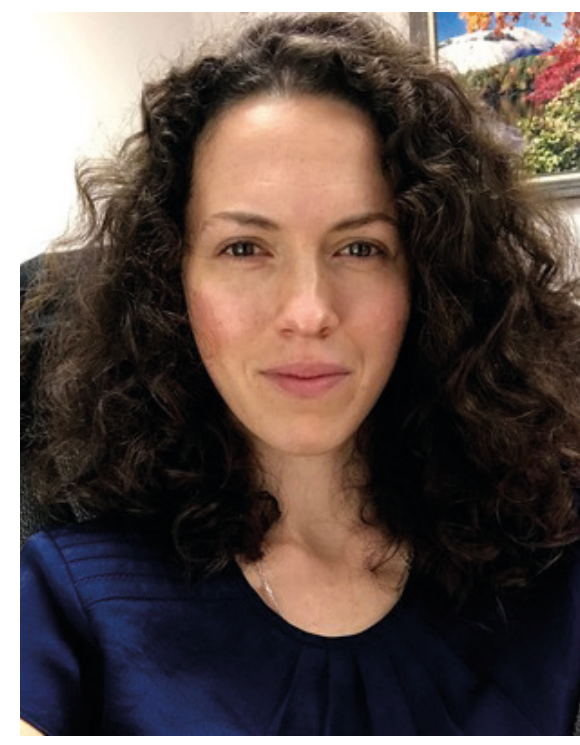

\section{Маркова Светлана}

Психологический центр Ажулии Медлин

(Атланта, штат АжорАжия, США)

clairmarkova@mail.ru

ORCID: 0000-0002-3765-4070

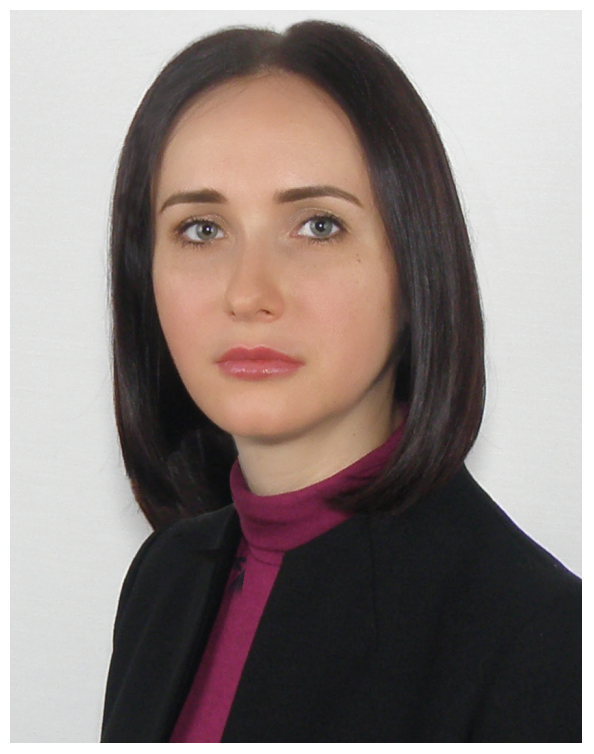

\section{Никитская Екатерина}

Московский университет

МВА России имени В.Я. Кикотя

(Москва, Россия)

katamax@yandex.ru

ORCID: 0000-0003-3187-6534
Научная статья

Проблема суициАов

\section{В поАростКовой}

и МолоАеЖной среАе:

факторы риска, профилактика

\section{суициАального повеАения}

\section{Аннотация}

Целью данной статьи является изучение современного подхода к профилактике суицида в школе. В статье анализируются статистические данные, важность и значимость изучаемой проблемы, рассматриваются причины суицида, факторы суицидального риска и меры по предотвращению суицидального поведения. Авторы подчеркивают особую роль школы в предотвращении самоубийств, дают информацию для учителей, администрации школы и школьных психологов, касающуюся данного вопроса, описывают актуальные для школы инструменты и программы, направленные не только на предотвращение суицидального поведения, но и на минимизацию возможного риска возникновения суицидальных намерений в будущем.

\section{Scientific article}

\section{Adolescent and Youth Suicide: Risk Factors and Approaches to Prevention}

\section{Abstract}

The aim of this article is to explore current approach to suicide prevention at school. The article provides information about statistics and the importance of the problem. It addresses risk and protective factors of suicide and its causes. In addition, it provides a detailed examination of the role of school in suicide prevention. The article contains information regarding specific interventions for staff members, administration and school psychologists. It discusses existing tools and programs the school has access to in order to prevent suicidal behaviors and ideations among students. 


\section{Svetlana V. Markova}

Medlin Treatment Center

(Atlanta, GA USA)

clairmarkova@mail.ru

ORCID: 0000-0002-3765-4070

\section{Catherine A. Nikitskaya}

Kikot Moscow University of the Ministry of Internal Affairs of Russia (Moscow, Russia)

katamax@yandex.ru

ORCID: 0000-0003-3187-6534

\section{Ключевые слова}

суицид, профилактическая работа школы, школьный психолог, подростки, факторы риска

\section{Keywords}

suicide, school prevention, school psychologist, adolescents, risk factors

Для цитирования: Для цитирования: Маркова, С. В., Никитская, Е. А. (2021) Проблема суицидов в подростковой и молодежной среде: факторы риска, профилактика суицидального поведения. Российский девиантологический журнал, 1(1), 127-136. doi: 10.35750/2713-0622-2021-1-127-136.

For citation: Markova, S. V., Nikitskaya, C. A. (2021) Adolescent and Youth Suicide: risk factors and approaches to prevention. Russian Journal of Deviant Behavior, 1(1), 127-136. doi: 10.35750/2713-0622-2021-1-127-136.

\section{Introduction}

1. Suicide, suicide ideations and attempts, self-harming behavior are significant public health concerns in school-age people around the world. Every minute, a suicidal attempt or a completed suicide is registered. Worldwide, suicide is the second leading cause of death for 15-29-year-olds. In 2019, approximately $75 \%$ of global suicides occurred in low- and middle-income countries (WHO, 2020) In Russia suicide is the second leading cause of death among people of all ages (Rosstat, 2020). Suicide has been the second leading cause of death for adolescents and young adults aged 15 to 24 in the United States, (CDC, 2019) and suicide attempts are significantly higher among youth, compared to adults. Suicidal thoughts are thoughts of suicide. They range from passive (eg, «I wish I was dead») to considering a specific method of suicide and developing a specific suicidal intent with action plans. Suicidal thoughts can be temporary or chronic, with some people experiencing passive suicidal thoughts for many years without attempting to do so. However, general terms such as «suicidal» that are often used in psychiatric literature may not reflect these nuances. Terms such as "active suicidal crisis" usually mean that a person is experiencing more than just passive suicidal thoughts; this often means that the person intended to react to these thoughts or even attempted suicide (Nugent, A.C., Ballard, E.D., Park, L.T. et al., 2019). Suicidal comments, self- harming behavior, and suicide attempts are more common than completed suicide in school-age people, and are associated with number of other negative problems, such as co-morbid mental disorders, poor educational and vocational outcomes, and premature death due to other causes. Studies show that people who attempt suicide in adolescence have a higher likelihood of mental health treatment utilization, mental illness diagnosis, and adult suicide (Cha, Franz. et al., 2018).

\section{International Approach to Understanding Suicide}

While there are psychological theories about the underlying causes of suicide, there are also other approaches. For example, Klonsky and May advocate a three-tiered theory in which the causes of suicidal thoughts are rooted in pain and hopelessness, and social solidarity serves as a third - and protective - factor against the degeneration of ideas into behavior (Klonsky, May., 2015). Such models separate the processes underlying thoughts and behavior, as first proposed by Joiner (Joiner., 2005.)

There are other factors, such as economical, that is recognized worldwide as one of the leading causes of suicide. (Nordt et al., 2015). There is data obtained in the USA, Greece and other European countries during this period, suggesting that economic situation that led to rising unemployment, contributed to increased numbers of suicides in this county (Sinyor, Tse, Pirkis. 2017). A study examining the differences in suicide rates between European countries has shown that both economic and climate variables have a significant impact (Fountoulakis et al., 2016). Another recent study found that Chinese psychiatrists are more stigmatizing and less empathetic towards people with mental illness than non-medical members of the urban community. There is important evidence that stigma about suicide can increase the risk of suicide in vulnerable people (Jiao et al. 2014).

Today, it is known that the etiology of suicide is complex and multifactorial: suicides may be associated with mental illness, social, economic, cultural or political factors, therefore, making it clear that suicide prevention should 
address several areas outside of the medical suicide model.

Almost 100 years ago, the most comprehensive definition was formulated by E. Durkham: "Suicide is any death that is a direct or indirect result of a positive or negative act committed by the victim himself, if the victim knew about the expected results". In 1897, Emile Durkheim authored a phenomenon of suicide from a socio-cultural perspective. Specifically, Durkheim conceptualized suicide as stemming from four different factors encompassing ideas of community integration, sacrifice, moral confusion, and desperation (Durkheim, 1897).

E. Durkheim was the first to study suicidal behavior in 1897. According to E. Durkheim, it is customary to distinguish three types of suicidal behavior:

1. Anemic suicidal behavior - associated with crisis life situations, personal tragedies.

2. Altruistic suicidal behavior - committed for the benefit of others.

3. Selfish suicidal behavior - caused by conflict, both interpersonal and within personal, associated with the individual's rejection of social norms and requirements.

It was E. Durkheim who divided suicidal manifestations into: suicidal tendencies, suicidal attempts, completed suicides.

In modern science, there are two typological schemes of suicidal acts that can be applied to external and internal forms of suicidal behavior. All external forms are based on the target category: true suicide; demonstrative suicides. It is not uncommon for a demonstration suicide to end fatally, due to insufficient consideration of the circumstances. Internal forms of suicidal acts, in turn, are based on the category of personal meaning: appeal, protest, self-punishment, and avoidance.

In Russian psychological science there are several interesting approaches to the youth suicide, for example, by A.G. Ambrumova, N. D. Kibrik, E.M. Bruno. They highlight significant differences between adolescent suicide and adult suicide:

1. Lack of real desire and clearly understood purpose of suicide. Psychotherapeutic practice demonstrates that children and adolescents are not able to explain the reason according to which they made the decision to commit suicide (as a rule, usually, the suicide factor is perceived by the adolescent as a burdening problem for him, which is not possible for him to solve).

2. Lack of ability to verbalize your own feelings, share your own experiences with others, and as a result, inability to respond. Unspoken negative feelings accumulate in the already traumatized soul of a teenager, which intensifies the child's depressed state.

Yu.V. Popova noted in her research that in conditions of prolonged stress, a negative atmosphere in the family, and the lack of positive experience in dealing with stressful situations, self-destructive behavior can be perceived as a way to temporarily solve problems. And since in children and adolescents the affective response is characterized by stereotypical repetition, in the future the adolescent reacts to any problems as well.

The theory of A.G. Ambrumova is the most common in Russian suicidology (Ambrumova, 1983). According to her, the features of suicidal behavior in adolescence include:

1. Inadequate assessment of the results of autoaggressive actions. Death at this age is perceived vaguely, often as something temporary, similar to sleep and not related to it. In adolescents, there are no specific boundaries between a real suicidal attempt and blackmailing an autoaggressive bias. This fact makes for preventive purposes to consider all types of auto-aggression as a type of suicidal behavior.

2. Insignificance of motives, especially from the point of view of adults, to which adolescents explain suicidal attempts. It is with this that the difficulties of timely identification of suicidal factors and a significant number of unexpected cases for the surrounding are connected.

3. The presence of a connection between attempted suicide and deviant behavior: truancy, running away from home, conflicts with parents, minor offenses, early smoking, alcoholism, sexual excesses of drug addiction, etc.

There are many promising findings in research on suicide, particularly in the areas of prevention and intervention trials. However, some researchers have been reluctant to recommend adopting or scaling up many of these approaches because of inconsistencies in the research methodologies or inadequate reporting of trial information (e.g., people who have suicidal behavior may be excluded from clinical trials). As a result, systematic reviews and meta-analyses-the types used in the literature review and this summary report-do not draw firm conclusions. Current results suggest that suicide is often the influence of multiple factors that leads someone to die by suicide. Other determinants may include: marital breakdown, economic hardship, a change in physical health, a major loss, or a lack of social support. Both the factors that contribute to suicide and suicidal behavior, as well as the solutions, are complex and multifaceted. Accounting for these multiple levels of interaction is essential to developing an effective suicide prevention strategy that can adequately respond to the unique needs of populations with higher rates of suicide and recommend the best evidence-based care responses. Internationally, research prioritization has been an effective approach to address research challenges and seize opportunities to prevent suicide (Davis, Molock et al., 2014).

\section{Assessment}

When a teacher, psychologist, other students, or a social worker identify a student in a high-risk of potential suicide, such as talks about suicide, has suicidal thoughts, presents as exhibiting signs of agitation or intoxication, has a history of self-harming behavior, or displays symptoms and signs of suicidal thoughts or intent, the student must be seen by a school psychologist or school social worker 
as soon as possible to assess risk and refer the student to other professionals. If the school doesn't have mental health worker on campus, the students' parents need to be informed and referred to a psychological evaluation or risk assessment. Teachers, psychologists and social workers need also to be aware of other written or verbal threats made by the student. In case of written threats and suicidal notes, the student should be immediately referred to a psychologist. Also, the principal, teacher, or a school psychologist need to inform the parent or guardian of such threats and risks. If any staff member becomes aware of a suicide comments or attempt as well as of self-harming behavior by a student in an out-of-school location, the school personnel heed to inform the student's caretaker and school psychologist.

\section{Risk and Protective Factors}

Addressing the problem of youth suicide requires collaborative and synergistic action across various community institutions and agencies, a position that has been codified in key documents informing suicide prevention initiatives. The World Health Organization recommends that policymakers and relevant stakeholders adopt a "comprehensive multisectoral strategy" to advance a public health agenda that prioritizes suicide prevention (Breux, Boccio, 2019).

There are multiple factors that can trigger suicidal behavior as well as prevent it. The family environment plays a key role in adolescents' well-being. The role of the family in the genesis of suicide is indicated by the study of suicidal motivation; problems of family trouble were revealed in more than $40 \%$ of cases of suicidal attempts and completed suicides. Moreover, family ties are a protective factor against suicide. Reliable, warm and trusting relationships are the key to an organically developing personality. Among the motives that prevent the commission of suicidal actions, one can single out: unwillingness to injure relatives, emotional attachment to loved ones. Thus, the impact of the family on a potential suicide is twofold: it can be a source of conflicts, or oppose the realization of the suicidal tendencies formed in the individual. Frequently, it is impossible to identify a special type of family or family circumstances that would inevitably create suicidal behavior. It can only be argued that some families provide better psychological protection for their members than others. In addition, in the same family the position of some members of the family members is more favorable than the position of others - some are quite satisfied with the system of existing family relationships, others are constantly experiencing mental stress and stress (Breux, Boccio, 2019).

The next most important subject of suicide prevention is school, since it is here that a teenager spends a large amount of time. The main «school» reason for suicidal behavior in adolescents is the violation of interpersonal relationships, since the main activity of adolescents is communication. Caretakers play the key role in suicide prevention; therefore, it is important for the school to inform them and involve them in decisions regarding the students' emotional and behavioral states, while school psychologist should advocate for the student's best interests. Caretakers who learn the warning signs and risk factors for suicide are more likely to reach for a professional support if necessary. Therefore, caretakers should be advised to take every statement regarding suicide and a wish to die seriously.

It is extremely important for students to have free access to mental health professionals, teachers they trust or other professionals in times of crisis. Having access to resources and support improves students' physical and psychological mental health, safety, academic performance, and social and emotional development.

There are risk and protective factors that increase or, consequently, decrease the risk of suicidal behavior. Risk factors are circumstances that increase the likelihood of a suicide attempt. The risk of suicide increases dramatically when a student has multiple risk factors or has long-term risk factors and negative experiences. These factors interact with each other, and the more they exist and the more they increase, the higher the risk.

The most common risk factors for suicide are:

Mental health:

- Mood and anxiety disorders

- Substance use disorders

- Eating disorders

Low frustration tolerance

Impulsiveness

Recklessness

Poor problem-solving skills

Perceiving yourself as too inadequate

Problems with alcohol or drugs

Previous suicide attempts

Somatic health issues

Early childhood history with trauma, abuse, neglect, or loss

Family characteristics

Family history of suicide or suicidal behavior

Divorce of parents

Death of significant others

Problems in the relationship between parents Цand children

Environmental factors

Bullying at school

Lack of respect and fair treatment

Protective factors are characteristics that can help reduce a person's risk of suicide. Such factors have not been studied as thoroughly as risk factors. Protective factors do not exclude a possibility of suicide but help build resilience. 
The following social and environmental factors include:

Getting effective mental health care

Positive relationships with family and peers

Access to religious institutions that support social groups

Individual factors: Emotional intelligence

Knowledge of problem-solving and coping skills

Regular physical activity

Spiritual faith and involvement in church

Resilience and frustration tolerance

Note that protective factors do not eliminate the risk entirely. There are periods when resilient students may be temporarily disturbed by a sudden increase in risk factors. Identifying them increases a positive outcome and helps to prevent suicide. Bullying is one of the most common risk factors and stressors in school life that teachers should be aware of. The relationship between bullying and suicide is very complex. Research shows that bullying can lead to feelings of isolation as well as depression and anxiety, which can contribute to suicidal behavior (SPRC, 2014).

Although the research has shown that young people who are bullied and those who bully others are at increased risk of suicidal behavior, young people who are already at risk of suicide (such as depression, anxiety, drug use, or other illnesses) and who are simultaneously involved intimidation or reliving other negative life events are most at risk. One study found that those who experience violence are 19 times more likely to develop suicidal thoughts than young people who have not previously been bullied (Hay and Meldrum, 2010).

Some children who are bullied have personality traits that increase the risk of victimization. Personal risk factors work in conjunction with other risk factors associated with other factors, including child abuse, domestic violence, and parental depression as well as school environment, including bullying, lack of supervision and school size (Arseneault, Bowes, \& Shakoor, 2010).

\section{School Role in Suicide Prevention}

The education system has been recognized as the logical place to promote suicide prevention efforts, and schools have taken a greater leadership role in identifying, referring and supporting youth with mental health needs. Kalafat stated that schools are responsible for the education, socialization and protection of youth. Activities related to suicide prevention are therefore compatible with the traditional mandates and tasks of a school system. In addition, positive and caring school environments that promote a sense of interpersonal connection, promote disclosure of concerns to supportive adults, and promote competencies related to mental wellbeing can serve as protective features that reduce the risk of suicide (Kalafat, 2003).
The impact of youth suicide affects their closest environment but also goes beyond the individual. Research indicates exposure to a suicide (e.g., schoolmate's suicide and personally knowing someone who died by suicide) predicts suicide ideation and attempts in others. The National Longitudinal Survey of Adolescent Health reveals that for the first year following a friend's death by suicide, peers experience heightened suicidal ideation and attempts, as well as higher rates of depression (Erbacher et al., 2015).

Protecting both physical and mental health of students is one of the goals of school philosophy and is an ethical obligation for all professionals working with youth. Suicide prevention efforts in schools are normally include school psychologists, class leaders, teachers, police officers or social workers. However, it requires a teamwork of professional and administration to develop effective suicide prevention strategies. School plays an essential role in prevention of suicide as schools are obligated to protect the safety of their students while they are in the school's care. The school psychologist is primarily involved in the prevention of suicidal behavior at school, according to the law of the Russian Federation. Fortunately, educational and pedagogical goals of schools are consistent with suicide prevention and other efforts to protect students. Many activities designed to prevent substance use, violence, academic and professional failure, and bullying. Another reason for school to engage in active prevention is that mental health affects academic performance (Erbacher et al., 2015). The psychologist's activities on the prevention of suicidal risk at school include interactions with the entire system as a whole. Also, if necessary, interagency interaction with medical, social and other organizations is carried out.

Preventive measures include the following forms:

1. Education - is carried out for all subjects of the educational process.

2. Increasing psychological stability of adolescents.

3. Identification of suicidal risk (diagnosis of suicidal risk factors).

4. Crisis intervention with a high risk of suicide.

Education is primarily aimed at students, since at the stage of the emergence of suicidal thoughts, adolescents turn, first of all, to friends, and only then to teachers, school psychologists, and parents. Also, it is the students who are the first to notice changes in their classmate, such as gloom, withdrawal, aggressiveness, fresh cuts and abrasions. Teaching adolescents to recognize the "markers" of this behavior can help at the stage of identifying children of the "risk group". And the children of this group themselves should be provided with exactly the help they need - knowledge about the factors of suicidal risk, how to call the hotline, how to recommend a friend, and contact a consultant. Teenagers need a form of safe self-disclosure, 
such as, for example, an individual or group meeting, chat or anonymous letters, where they can get important and necessary information for them, ask questions, learn about how they can help themselves and others in case of obsessive thoughts of suicide. Unfortunately, only about $25 \%$ of students tell adults about their friend's idea of suicide (Breux, Boccio, 2019). One of the most important tools and interventions that can be realized at school by a school psychologist, teachers, and social workers is series of organized events and lessons that serve a goal of building resilience in students.

Resilience building involves a series of individual or group sessions for students at risk and for all students.

Individual and group work with students includes:

- group trainings;

- individual consultations with children;

- planning with children their positive future;

- formation of positive thinking;

- optimizing relationships with parents and peers.

The goal of effective psychological work is a child's better understanding of his "I", increasing self-esteem, identifying conflicting emotions, practicing effective conflict resolution skills and more active communication with peers. If possible, parents also can be engaged in training, lessons or lectures organized by school administration or psychologist.

In order to increase the psychological competence of teachers, it is beneficial to conduct workshops and lectures: on the types of suicide, on the psychological and age characteristics of children, "markers" of suicidal behavior, on creating a safe atmosphere at school, on the possibilities of getting help in overcoming the crisis and places of obtaining it. Thus, it is crucial for them to be able to recognize the warning signs of suicide in students and to take appropriate steps if they notice such signs. Teachers who see students daily should be able to recognize changes in behavior, appearance, and academic performance that may indicate that this student is at risk for suicide (see Attachment for The Interview.) Some students may ask for help and disclose significant information to teachers or other staff members they trust. School psychologists or social workers should be trained to assess the suicide risk of individual students and have access to resources in order for them to refer the student to appropriate services that will help reduce their risk. Diagnosis of suicidal risk factors and the creation of a "risk group» is carried out by class teachers and a psychologist. Class teachers, in order to diagnose the suicidal risk of students, may invite parents to independently assess the suicidal risk of their children.

In addition, to staff training, school should educate parents and guardians to help them identify risk factors in children. Also, suicide prevention education is more effective when it is consistent both at home and in school (Sharaf et al., 2009). Parents' education, to a large extent, takes place only at parent meetings or individual consultations. A psychologist, together with a teacher, needs to plan speeches at meetings in order to inform parents about the psychological and age characteristics of children, about healthy and safe psychological atmosphere at home, about the available psychological services, about the behavioral features of a teenager with suicidal intentions. Involving parents is essential in order to school efforts appropriately target the needs of its students.

Since the school is a government agency primarily responsible for education and social development of young people, the school environment can contain risky behavior and identify and support people at risk. School codes and charters include a mandate not only to teach but to protect students. In this way, schools provide a logical environment for preventive action. Increasing demands on schools require suicide prevention programs to match the school's needs and culture and use school resources effectively. Effective programs need to be not only context sensitive, but also (a) have a theoretical basis, (b) use evidence-based implementation, and (c) be ecological. (Kalafat, 2001).

Prevention plans are definite or general. Assorted programs address specific issues such as risk behaviors, substance use, violence, sexual behavior, or suicide. they are usually designed for recruitment and health programs to systematically enroll the target population and are maintained over time. However, schools are notified of such programs to the extent that they limit the curriculum. One reason to turn to more general plans is that definite plans that focus on specific risk behaviors are ineffective. Such programs are aimed at promoting a number of safety factors that have individual and environmental characteristics that mitigate the occurrence of complex behaviors, even in groups characterized by multiple risk factors. Some studies have found that they are more powerful predictors of effects than risk factors. Furthermore, the programs that promote common safety factors such as interpersonal skills, coping skills, family relationships, and school performance mitigate the effect of risky behaviors, including substance use, defiant and aggressive behavior, and probability of extensive sexual behavior and early pregnancy (Dushkin et al., 2021). Although these comprehensive programs do not include suicide in their outcome assessments, there is some evidence of a link between school and social norms and the connection between suicidal thoughts and plans (Breux, Boccio, 2019).

Due to overlaps of risk factors such as suicide and drug use and coping skills issues, these programs may moderate suicidal behavior. There are research data that support the effectiveness of the programs, they also clearly refer to the effective use of real and school resources in conjunction with schools' socialization and protection programs. However, such plans alone may not be enough to helps 
student cope with suicidal ideations. Researchers suggest that modifying school climate and developing community skills and coping-skills programs would take significant amount of time. These efforts should be complemented with specific instruction for specific risk behaviors. Furthermore, although conditions and coping skills may support the appearance of some mental health disorders, such symptoms often go undiagnosed and require appropriate therapeutic and pharmacological interventions. For example, some students may be viewed as more flexible and resilient because even though they come from a highrisk environment, they are educated and have better social skills. However, psychological evaluations demonstrated that they experienced more symptoms of depression and anxiety than their peers (Singer et al., 2018). Therefore, there is a need to prepare schools to respond effectively to suicidal and suicidal individuals.

The overarching goal of the universal programs is to create competent school communities in which all participants are responsible for buparotradic safety and a strong specific program concept (Singer et al., 2018). There are several concepts:

- Most young people are more likely to trust their friends than adults (Kalafat, 2003);

- Adolescents with history of mental health issues or substance use prefer peer support over adults (Fazel et al., 2014);

- Adolescents, especially male, unresponsive to other unresponsive peers (Fazel et al., 2014);

- Only $25 \%$ of peer-to-peer believers in the story have attempted suicide (Kalafat, 2003);

- Adults can be seen as a protective factor for various disadvantaged young people.

- There is also evidence that helping peers by other young people can benefit them as participation in fostering interactions can lead to prosocial behavior and reduce problem behaviors and is linked to social competence indicators that can move on to other challenging situations (Fazel et al., 2014). Therefore, school suicide prevention programs should be designed in a way that increases the chances that school administrators, teachers, school psychologists, and other students will come into contact with young people at risk, will be able to identify them, give them an appropriate initial answer, know how to get help from them, and are constantly inclined to do so. The role of schools in this approach is essential, although, limited to identifying students at risk and referring them to further interventions.

To achieve these objectives, comprehensive suicide prevention programs include important steps and components, which are implemented in the following order:

1. Administration orders that policies and procedures are in place, conduct assessments to identify and graduate students at risk, and to ensure that social workers, teachers and psychologists have all needed information for appropriate referrals. These steps usually take minimal amount of time during the meeting.

2. School training for all teachers, social workers, and staff to identify problematic and at-risk students, steps of their appropriate response and effective referral. This training includes the role of the school, risk factors and warning signs, myths about suicide, initial response and referral guidelines, an overview of school rules, and school resources as well as community resources. Goalkeeper training can be done in 2 hours and can be repeated about once every year or two years (Kalafat, 2003).

3. Parent training, which includes material similar to the training of school goalkeepers, as well as containment strategies. It can be a half-hour presentation, often combined with other presentations or activities, because parents do not always see how important suicide prevention is to them (Kalafat, 2003).

4. Training of school partners such as police officers and social workers, including policies and procedures for effective response and coordination with schools and families (Dushkin et al., 2021). When the students struggle from mental health issues and these issues cannot be addressed by school, an appropriate referral should be given to students and their parents. Also, a constructive dialog and coordination between school and mental health professional is required. Also, in response to adolescents' reluctance to use mental health services, there are some services and intervention that can be provided by school psychologists as well as psychoeducation for students and their caretakers that can be completed by school resources.

5. Student classes should include a psychoeducation about healthy lifestyle, understanding of stressors, and possible interventions. Again, general problem-solving, decision-making, and similar programs can form the basis of this categorical suicide response program in educational classes by their teachers or school psychologists. Classes may include workshops, lectures, movie watching and role-playing to educate them how to recognize and react to peers in distress and what resources and interventions exist. These actions are not intended to prevent suicidal feelings or behaviors. Rather, they emphasize help-seeking skills and resources and are aimed primarily at students who are often exposed to at-risk peers and, secondly, at-risk students themselves. Classes include suicide materials related to seeking help. This includes warning signs and myths, such as children who talk about suicide but commit suicide, and people who are seriously planning to kill themselves do not want any help. Focusing on seeking help refers to other risk behaviors, such as interpersonal violence, as recent events have shown that peers and adults were often aware of warning signs but unable to act (Kalafat, 2003). Because classes engage in more than one risky behavior, they make efficient use of school resources.

The programs that include various steps, participants and components are comprehensive as they cover 
administration, community partners, psychologists, staff members, parents, and students. It is important to understand, that training school staff to appropriate respond to students at risk and teaching students to seek adult help for their friends in distress may not be sufficient enough. It is crucial that schools strengthen the link between students and adults, such as teachers and other staff, at school. That is, research indicates that school schedules, the disciplinary and evaluative role of adults, and other adult characteristics of many schools make students psychologically, timely, and culturally inaccessible (Singer et al., 2018). These issues need to be addressed if students are to follow the lessons learned in health lessons. In this context, the programs mentioned above in this article, which promote protective factors, including a closer link with the school, may be useful.

Comprehensive prevention programs usually fit into school resources and policies because they have an educational rather than a clinical psychological focus; the classroom curriculum may consist of flexible and independent lesson plans provided by teachers and not by additional partners or consultants; and they easily fit the existing workshop and lessons structure without requiring additional activities or resources. Appropriate learning principles are also used in the student curriculum, such as interpersonal and individual activities, skills practice and positive feedback, as well as strengthening and recognizing students' experiences (in this case, dealing with problems with peers). In addition, external participants, such as police officers or social workers may be invited into the same lesson structure with additional lectures or activities.

\section{Conclusion}

Suicide is one of the most urgent and concerning problems for international mental health professional community. There are various program and approaches to prevention and treatment of suicide that differ from country to county but also have similarities. Many countries have also adopted national suicide prevention strategies that attempt to reduce deaths by suicide through multipronged approaches: increasing awareness about suicide and safe/best practices (general population, school settings, professionals, including media), training initiatives around the most promising intervention practices (medical professionals and practitioners, community members and "gatekeepers" such as parents, spouses/ partners, friends, teachers, caseworkers), and improving care for people at increased risk (through screening and treating underlying psychiatric disease, improving organization of services). Coordinating research and integrating expertise from various fields is a crucial step toward better understanding what drives individuals to harm themselves and finding the most appropriate and effective tools to help them.

\section{References}

Ambrumova, A. G. (1983). Suicide as a phenomenon of socio-psychological maladjustment of personality. Actual problems of suicidology, 82, 6-28.

Arseneault, L., Bowes, L., Shakoor, S. (2010). Bullying victimization in youths and mental health problems: 'much ado about nothing'? Psychological medicine, 40(5), 717-729.

Breux, P., Boccio, D. E. (2019). Improving Schools' Readiness for Involvement in Suicide Prevention: An Evaluation of the Creating Suicide Safety in Schools (CSSS) Workshop. International journal of environmental research and public health, 16(12), 2165.

Centers for Disease Control and Prevention. (2019). Suicide Facts at a Glance. Retrieved from www.cdc.gov/ violenceprevention/pdf/suicide-datasheet-a.pdf.

Cha, C., Franz, P., Guzman, E., Glenn, C., Kleiman, E., Nock, M. (2018). Annual Research Review: Suicide among youth - epidemiology, (potential) etiology, and treatment. Journal of Child Psychology and Psychiatry, 59(4), 460-482. doi: $10.111 /$ jcpp. 12831

Davis Molock, S., Heekin, J. M. et al. (2014). The baby or the bath water? Lessons learned from the National Action Alliance for Suicide Prevention Research Prioritization Task Force literature review. American journal of preventive medicine, 47(3 Suppl 2), 115-121.

Durkheim, E. (1897). Suicide: a study in sociology. New York: Free Press.

Dushkin, A. S., Geyzhan, N. F., Dushkina, E. V. (2021) Prevention of antisocial behavior of minors in the process of interaction between a social worker and employees of the internal affairs bodies. Questions of pedagogy, (2-1), 46-49.

Dushkin, A. S., Goncharova, N. A., Dushkina, E. V. (2021) On the organization of psychoprophylactic work with minors who are registered in the departments for juvenile affairs of the internal affairs bodies. Modern Science, (2-1), 356-360.

Erbacher, T. A., Singer, J. B., Poland, S. (2015). School Liability and Implications for Best Practice. Suicide in schools: A practitioner's guide to multi-level prevention, assessment, intervention, and postvention (50-72). New York: Routledge, Taylor \& Francis Group. 
Fazel, M., Hoagwood, K., Stephan, S., Ford, T. (2014) Mental health interventions in schools 1: Mental health interventions in schools in high-income countries. Lancet Psychiatry, (1), 377-387.

Fountoulakis, K. N., Chatzikosta, I., Pastiadis, K., Zanis, P., Kawohl, W., et al. 2016. Relationship of suicide rates with climate and economic variables in Europe during 2000-2012. Ann General Psychiatry, (15), 19.

Hay, C., Meldrum, R. C., Mann, K. (2010). Traditional Bullying, Cyber Bullying, and Deviance: A General Strain Theory Approach. Journal of Contemporary Criminal Justice, (26), 130-147.

Jiao, Y, Phillips, M. R, Sheng, Y, Wu, G, Li X, Xiong, W, et al. (2014). Cross-sectional study of attitudes about suicide among psychiatrists in Shanghai. BMC Psychiatry, (14), 87.

Joiner, T. E. (2005). Why people die by suicide. Cambridge: Harvard University Press.

Kalafat, J. (2003). School approaches to youth suicide prevention. American Behav. Science, (46), 1211-1223.

Klonsky, E. D, May, A. M. (2015). The three-step theory (3ST): a new theory of suicide rooted in the "ideation-to-action" framework. Int Journal Cogn Therapy, (8), 114-29.

Nordt, C., Warnke, I., Seifritz, E., Kawohl, W. (2015). Modelling suicide and unemployment: a longitudinal analysis covering 63 countries, 2000-11. Lancet Psychiatry, (2), 239-45.

Nugent, A. C., Ballard, E. D., Park, L. T. et al. (2019). Research on the pathophysiology, treatment, and prevention of suicide: practical and ethical issues. BMC Psychiatry, (19), 332.

Rosstat. Statisitcs.(2020). https://rosstat.gov.ru

Sharaf, A. Y., Thompson, E. A., Walsh, E. (2009). Protective effects of self-esteem and family support on suicide risk behaviors among at-risk adolescents. Journal of Child and Adolescent Psychiatric Nursing, 22(3), 160-168.

Singer, J. B., Erbacher, T. A., Rosen, P. (2018). School-based suicide prevention: A framework for evidence-based practice. School Ment. Health.

Sinyor, M, Tse, R, Pirkis, J. (2017). Global trends in suicide epidemiology. Current Opinion Psychiatry, (30), 1-6.

Suicide Prevention Resource Center (SPRC). (2014). Suicide and Bullying (Issue Brief). Newton, MA: SPRC.

Treatment for Suicidal Ideation, Self-harm, and Suicide Attempts Among Youth. Rockville, MD: National Mental Health and Substance Use Policy Laboratory. Substance Abuse and Mental Health Services Administration, 2020

World Health Organization, Suicide. (2020). http://www.who.int/mediacentre/factsheets/fs398/en/

\section{Attachment \\ Conduct suicide risk assessment:}

1. Can you tell me more about (reason for the call or conversation)? (e.g., Tell me more about the assignment you submitted, the message you left, etc.)

2. Are you thinking about killing yourself (use whatever language/words that they use).

If yes, have you thought about when you would do it?

If yes, how long have you been feeling this way or when did you start feeling this way?

3. Have you ever shared your thoughts about suicide with anyone else or told anyone how you feel? If yes, to whom, how did they respond, what did they say?

4. Do you have a plan to harm or kill yourself? Do you know how you would kill yourself? If yes, what is your plan and how would you do it.

5. Ask if student has immediate access to any of the identified means of hurting or killing themselves. If yes, ask where the item is in proximity to them and make a notation to follow up with parent/guardian about decreasing access.

6. Have you ever had thoughts of suicide in the past? If yes, how long ago?

7. Have you ever tried to kill yourself? If yes, how long ago, what did you do and what happened?

8. Have you ever tried to hurt (self-injurious behavior) yourself? If yes, when was the last time you tried to hurt yourself, did you injure yourself when you tried, what did you use, what did you do to hurt yourself, where on your body did you injure yourself, what were you hoping would happen, did you want to die and do you know what it means to die?

9. In the past year, have you ever felt so sad that you stopped doing things that you enjoy? If yes, what are those activities and do you still like doing those things? Are there new things that you like to do?

10. Has anyone close to you ever died by suicide? If yes, who, when, and how? 
11. Has someone close to you died recently or have you been separated from someone who is important to you? If yes, who, when and how?

12. Is anything traumatic/scary happening or happened to you? If yes, describe. m. Does anyone call you names, hit you or make you feel bad about yourself? If yes, describe. n. Do you use alcohol or drugs? If yes, which ones, how often, how much?

\section{Информация об авторах:}

Светлана Маркова - кандидат психологических наук, Психологический центр Джулии Медлин, Атланта, штат Джорджия, США.

Екатерина Никитская - кандидат педагогических наук, доцент, Московский университет МВД России имени В.Я. Кикотя, Москва, Россия.

\section{About the authors:}

Svetlana V. Markova - PhD Medlin Treatment Center Atlanta, GA USA.

Catherine A. Nikitskaya - PhD Kikot Moscow University of the MIA of Russia, Moscow, Russia.

Статья поступила в редакцию 30.03.2021; одобрена после рецензирования.11.05.2021; принята к публикации 17.05.2021.

The article was submitted March 30, 2021; approved after reviewing May 11, 2021; accepted for publication May 17, 2021.

Авторы заявляют об отсутствии конфликта интересов.

The authors declare no conflicts of interests.

\section{ВкиаА авторов}

Светлана Маркова - проведение эмпирического исследования, сбор и интерпретация результатов.

Екатерина Никитская - работа с теоретическими источниками, интерпретация результатов.

\section{Authors“ contribution}

Svetlana Markova - conducting an empirical research, collecting and interpreting the results.

Catherine Nikitskaya - work with theoretical sources, interpretation of the results. 